\title{
Citrus psorosis virus coat protein-derived hairpin construct confers stable transgenic resistance in citrus against psorosis $A$ and $B$ syndromes
}

\author{
A. De Francesco • N. Costa • M. L. García
}

Received: 22 June 2016/ Accepted: 13 November 2016

(C) Springer International Publishing Switzerland 2016

\begin{abstract}
Citrus psorosis virus (CPsV) is the causal agent of psorosis, a serious and widespread citrus disease. Two syndromes of psorosis, PsA and PsB, have been described. PsB is the most aggressive and rampant form. Previously, we obtained Pineapple sweet orange plants transformed with a hairpin construct derived from the $\mathrm{CPsV}$ coat protein gene (ihpCP). Some of these plants were resistant to $\mathrm{CPsV}$ 90-1-1, a PsA isolate homologous to the transgene. In this study, we found that expression of the ihpCP transgene and siRNA production in lines ihpCP-10 and -15 were stable with time and propagation. In particular, line ihpCP-15 has been resistant for more than 2 years, even after re-inoculation. The ihpCP plants were also resistant against a heterologous $\mathrm{CPsV}$ isolate that causes severe PsB syndrome. Line ihpCP15 manifested complete resistance while line ihpCP10 was tolerant to the virus, although with variable
\end{abstract}

Electronic supplementary material The online version of this article (doi:10.1007/s11248-016-0001-2) contains supplementary material, which is available to authorized users.

A. De Francesco - M. L. García ( ()

Instituto de Biotecnología y Biología Molecular, CCT-La Plata, CONICET - UNLP, calles 47 y 115, 1900 La Plata, Buenos Aires, Argentina

e-mail: garcia_m@biol.unlp.edu.ar

N. Costa

Estación Experimental Agropecuaria, INTA Concordia, Ruta Provincial 22 y vías del Ferrocarril, 3200 Concordia, Entre Ríos, Argentina behaviour, showing delay and attenuation in PsB symptoms. These lines are promising for a biotech product aimed at eradicating psorosis.

Keywords Citrus psorosis virus - Hairpin-RNA . Psorosis A · Psorosis B - Transgenic sweet orange · Virus resistance

\section{Introduction}

Psorosis is a serious, graft-transmissible and widespread disease, affecting most citrus varieties worldwide, particularly those in North and South America and in the Mediterranean basin (Roistacher 1993). In Argentina, psorosis causes substantial yield losses (Danós 1990; Anderson 2000; Zanek et al. 2006), and although the budwood certification program has been successful, it has been insufficient to eradicate the disease. Typical symptoms in adult trees include bark scaling, pustules and gum accumulation on the trunk, flecking, chlorotic spots, and necrotic shock of young shoots.

The causal agent of psorosis is Citrus psorosis virus (CPsV), type member of the genus Ophiovirus, family Ophioviridae (García et al. 1994; Milne et al. 2000; Moreno et al. 2015). CPsV is tripartite and its genome consists of three single-stranded RNAs (ssRNAs) of negative polarity. CPsV RNA 1 encodes the RNAdependent RNA polymerase (Naum-Ongania et al. 
2003) and the $24 \mathrm{kDa}$ protein, which interferes with the microRNA (miRNA) processing (Reyes et al. 2015). RNA 2 encodes the movement protein (Robles Luna et al. 2013) and RNA 3, the coat protein (Sánchez de la Torre et al. 1998).

Two types of psorosis, called psorosis A (PsA) and psorosis B (PsB), were initially described by Fawcett and Klotz (1938). PsA and PsB syndromes are both graft-transmitted and can be induced by various tissues of the same tree (Velázquez et al. 2012). PsA induces bark scaling, restricted to the main trunk and limbs, and chlorotic flecks and spots in young leaves. It can also cause dieback and decrease fruit yield. PsB is more aggressive, showing extensive bark scaling that also affects thin branches and limbs, and causes blotching in old leaves, with brownish gum-impregnated eruptions and pustules on the leaf underside (Roistacher 1991; Moreno et al. 2015). Both syndromes can be observed in graft-inoculated sweet orange (Citrus sinensis) seedlings, under greenhouse conditions. Chlorotic flecks and spots on young leaves and a shock reaction with shoot necrosis occur in the first flush, after inoculation with select isolates associated with both syndromes. However, spots with gum in leaves, or gum and pustules in twigs are characteristic symptoms of PsB. Roistacher (1991) described biological indexing as a diagnosis test specific for PsA that is based on cross-protection using PsB as a challenge. Sweet orange seedlings are graft-inoculated with tissue of the candidate tree and subsequently grafted with a PsB source. A sample taken from a putative PsA-infected tree can prevent the appearance of the typical PsB symptoms. The mechanism of crossprotection between the two types of psorosis remains unknown, although a silencing mechanism (Velázquez et al. 2010), or other complex interaction involving viral proteins (Folimonova et al. 2014), could be involved.

RNA silencing is one of the mechanisms that plants use to defend themselves against viruses (Molnar et al. 2010; Axtell 2013). RNA silencing is triggered by the presence of double-stranded RNA (dsRNA) molecules, which cause a sequence-specific shutdown in the expression of genes containing sequences identical or highly similar to the initiating dsRNA (Baulcombe 2004). The use of dsRNA to trigger RNA silencing can be achieved by transformation with sense and antisense sequences separated by an intron (intronhairpin constructs). After transcription, the resulting hairpin RNA acts as a strong inducer of RNA silencing (Fire 1999; Smith et al. 2000).

Previously, we generated transgenic sweet orange plants expressing hairpin-RNA structures with a fragment of the CPsV coat protein gene ( $c p$ ) (Reyes et al. 2011). These transgenic lines, called ihpCP, induced post-transcriptional gene silencing (PTGS) of the $c p$ gene, and were resistant to the homologous isolate, which causes a PsA syndrome in nontransgenic (non-tg) sweet orange plants. Some ihpCP lines were asymptomatic and no virus was detected during three successive flushes (Reyes et al. 2011). In this work, we characterise two of these ihpCP transgenic lines for transgene expression stability with time and propagation and evaluate both their resistance 2 years post-inoculation (ypi) and their behaviour when challenged with a heterologous isolate causing PsB syndrome.

\section{Materials and methods}

Viral isolates and citrus propagation

For challenge assays, Argentinian CPsV isolates of PsA, CPsV 90-1-1, and PsB. CPsV 189-34. were used, both belonging to EEA INTA Concordia collection (Entre Ríos, Argentina).

For propagation of transgenic ihpCP lines, 6110 and 6115 (hereafter referred to as ihpCP-10 and -15), and non-tg Pineapple sweet orange (C. sinensis L. Osb.), ten replicates of each line and non-tg were prepared by budgrafting onto 10-12-month-old non-tg rough lemon (Citrus jambhiri Lush) seedlings, and the non-tg control. When scions grew over $30 \mathrm{~cm}$ (after 10-12 months) leaf material was taken for molecular analysis, and were subsequently graft-inoculated with CPsV.

\section{Graft-inoculation and symptom observation}

Replicates were inoculated by grafting on the scion with one piece of $\mathrm{CPsV}$-infected bark. The grafted inoculum piece remained throughout the entire challenge period. Symptoms were evaluated on mature leaves and limbs of CPsV-inoculated plants and noninoculated controls, for three successive flushes (6 months per flush). We defined a PsB symptomseverity scale ranging from 1 to 15 . A maximum value was given to bark gum, which is the most severe PsB 
symptom, and from this value, the remaining PsB symptoms were assigned. Lower scores were assigned to PsA symptoms (shock reaction and various kinds and intensities of leaf chlorosis, from 1 to 6), according to Reyes et al. (2016). The scores assigned in the scale were: mild flecking and mild spots $=1$; moderate flecking and moderate spots $=2$; severe flecking and severe spots $=3$; mild shock $=4$; moderate shock $=5$; severe shock $=6$; mild leaf gum $=7$; moderate leaf gum $=8$; severe leaf gum $=9$; mild limb blotch $=10$; moderate limb blotch $=11$; severe limb blotch $=12$; mild bark gum $=13$; moderate bark gum $=14$; and severe bark gum $=15$. The overall sum was calculated for each group of plants. No mean value was calculated because the same number of individuals (seven $\mathrm{CPsV}$-inoculated replicates) were assayed per group.

In silico analysis

Sequence alignment of the ihpCP region and CPsV 189-34 RNA 3 partial sequence (Genbank accession numbers FJ495195.1 and AM236000.1, respectively) was obtained using the Clustal 2.1 multiple sequence alignment algorithm. The effective silencing RNA (siRNA), potentially produced by the ihpCP transgene, was predicted in silico using the siRNA design tool (http://jura.wi.mit.edu/bioc/siRNAext/) and Block-iT RNAi Designer software (https:// rnaidesigner.invitrogen.com/rnaiexpress), as described by Di Nicola-Negri et al. (2010).

\section{RNA isolation and cDNA synthesis}

Total RNA was extracted from $200 \mathrm{mg}$ of fresh leaf tissue ground in liquid nitrogen, mixed with $1 \mathrm{ml}$ of TRI Reagent (Molecular Research Center, Cincinnati, $\mathrm{OH}$, USA) and processed according to the manufacturer's instructions. RNA extracts were re-suspended in $25 \mu \mathrm{l}$ of RNase-free water and quantified by absorbance at $260 \mathrm{~nm}$. A $2 \mu \mathrm{g}$ aliquot of total RNA in a volume of $0.5-5 \mu \mathrm{l}$ was digested with RQ1 RNase-free DNase (PROMEGA, Madison, WI, USA) for $1 \mathrm{~h}$ at $37^{\circ} \mathrm{C}$ in a final volume of $10 \mu$, following the manufacturer's specifications. After DNase treatment, $5 \mu \mathrm{l}$ of the preparations containing $1 \mu \mathrm{g}$ of total RNA were retro-transcribed (RT) with Maloney murine leukaemia virus reverse transcriptase (PROMEGA) in a final volume of $25 \mu$ l. Reactions were conducted using specific or reference primers, dNTPs, buffer, and enzyme, at the concentrations specified by the manufacturer, and 12 units of RiboLock RNase Inhibitor (Thermo Scientific, Waltham, MA, USA), for $1 \mathrm{~h}$ at $42{ }^{\circ} \mathrm{C}$. To confirm the efficiency of DNase treatment, qPCR was performed without previous cDNA synthesis and considered as a negative control of RT-qPCR assays.

\section{Transcript detection}

The ihpCP transcript was measured by RT-qPCR in five individuals of each line (in three independent determinations, with technical duplicates). SYBR green-based RT-qPCR was performed in a fluorescent quantitative detection system (FQD-48A) (BIOER, Hangzhou, China), as described by De Francesco et al. (2015). The reactions were performed in a total volume of $20 \mu \mathrm{l}$ using $5 \times$ HOT FIREPol EvaGreen qPCR Mix (Solis BioDyne, Tartu, Estonia) with primers CP1c (5' GTTCAAGATGGAGCAAGTTG ATGG $\left.3^{\prime}\right)$ and CP3 (5' GAGACCCTTGTGT AAAAACCAGCAC $3^{\prime}$ ) at $25 \eta \mathrm{M}$ and $1 \mu \mathrm{l}$ of cDNA. The amplification conditions were as follows: one cycle at $95{ }^{\circ} \mathrm{C}$ for $5 \mathrm{~min}$ followed by 44 amplification cycles of $95{ }^{\circ} \mathrm{C}$ for $20 \mathrm{~s}, 56{ }^{\circ} \mathrm{C}$ for $30 \mathrm{~s}$ and $72{ }^{\circ} \mathrm{C}$ for $20 \mathrm{~s}$, and one final elongation step at $72{ }^{\circ} \mathrm{C}$ for $5 \mathrm{~min}$. Final products were checked by electrophoresis on $2 \%$ (w/v) tris-acetate-EDTA (TAE) agarose gel stained with ethidium bromide. Data were analysed using the Line-gene K system and the FQD-48A software built into the device (BIOER). To normalise the quantification, $C$. sinensis ubiquitin transcript was selected as a reference gene, as previously reported (De Francesco et al. 2015), using the primers ubqtL (5'TCTTCA CCTCGTGCTTCGTCTCCGT3 $\left.{ }^{\prime}\right)$ and ubqtR (5'GT CCTGGATCTTGGCCTTGACGTTG $3^{\prime}$ ), under the same amplification conditions.

siRNA isolation and northern blot

The abundance of siRNA was monitored by northern blot analysis. Total RNA was extracted with TRI Reagent (Molecular Research Center), as described above, from $1 \mathrm{~g}$ of citrus leaves pooled from all replicates. RNA $(100 \mu \mathrm{g})$ from each pooled sample were separated on $17 \%$ polyacrylamide gels containing $7 \mathrm{M}$ urea and $0.5 \mathrm{X}$ TBE buffer (tris $50 \mathrm{mM}$, boric acid $45 \mathrm{mM}$, EDTA $0.5 \mathrm{mM}$ ) and transferred to a 
positively charged nylon membrane (Roche Diagnostics Corporation, IN, USA) by a Bio-Rad (Hercules, CA, USA) transfer unit where they were chemically fixed, according to Pall and Hamilton (2008). The probe was ${ }^{32} \mathrm{P}$-radiolabelled oligodeoxynucleotides complementary to the ihpCP sequence (primers CP1c, CP3, hp1CP 5'AATCCTCGAGCTTGTTCAAGATG GAGC $3^{\prime}$, and hpCP2b 5'GGAGCATGGCTCAGCT CCTCACTG $3^{\prime}$ ). Hybridisation was performed at $45{ }^{\circ} \mathrm{C}$ overnight, and after washing, the membrane was exposed. Signals were detected by autoradiography.

\section{CPsV detection}

To test for virus infection, leaf tissue was collected and analysed by two methods: RT-PCR, amplifying a viral RNA 2 fragment, and triple-sandwich immunoassay (TAS-ELISA), with horseradish peroxidase, to detect the CPsV coat protein.

RT-PCR was performed with primers A (5'TAGA TCCATGCTCAGTCACC $3^{\prime}$ ) and B (5'TTGACAAT GATGGACACTGG $3^{\prime}$ ) designed from RNA 2, and amplifying a $370 \mathrm{bp}$ fragment. cDNA was synthesised as described above, using $1 \mu \mathrm{l}$ of cDNA as the template. PCR was performed in a Perkin-Elmer 2400 apparatus. The thermo-cycling conditions were: initial denaturation at $94{ }^{\circ} \mathrm{C}$ for $5 \mathrm{~min}$; followed by 35 cycles at $94{ }^{\circ} \mathrm{C}$ for $10 \mathrm{~s}, 50{ }^{\circ} \mathrm{C}$ for $10 \mathrm{~s}$ and $72{ }^{\circ} \mathrm{C}$ for $50 \mathrm{~s}$; with a final elongation step at $72{ }^{\circ} \mathrm{C}$ for $4 \mathrm{~min}$. PCR products were analysed by electrophoresis on $2 \%$ (w/v) TAE agarose gel stained with ethidium bromide.

TAS-ELISA was carried out as previously described (Zanek et al. 2006), with A376 polyclonal antiserum at 1/7500 dilution, monoclonal antibody 13C5 (IgG) at 1/10,000 dilution, and conjugated antibody, goat anti-mouse-HRP $\operatorname{IgG}(\mathrm{H}+\mathrm{L})$ peroxidase conjugate (Jackson ImmunoResearch Laboratories, Inc., West Grove, PA, USA) at a dilution of 1/2500. Each sample was analysed in triplicate, from the same extract. Control samples were also prepared: infected plants, positive control; healthy, non-tg, noninoculated plants and extraction buffer as negative controls. Optical density (OD) values equal or higher than three times the average of the healthy non-tg control $(\mathrm{H})$ were considered positive for detection and diagnosis of CPsV (Alioto et al. 1999; Martín et al. 2004; Zanek et al. 2006). TAS-ELISA values were expressed as the ratio of inoculated replicates (I) to (H), i.e. I/H.
Statistical analysis

Statistical analysis was performed through a one-way ANOVA test with $95 \%$ confidence i.e. significance set at $P<0.05$.

\section{Results}

Transgene expression is stable in vegetative replicates of the ihpCP lines

Reyes et al. (2011) showed that ihpCP-resistant citrus lines accumulated transgene-derived siRNA (ihpCPsiRNA), and the siRNA level remain unchanged after inoculation with the homologous CPsV 90-1-1 isolate. These results indicated that the virus was unlikely to have multiplied, due to a gene silencing mechanism. The transgene expression stability in transgenic woody plants cannot be assessed in successive generations due to the long generation cycles of woody plants. Furthermore, it is not common citriculture practice due to the progeny variability. Instead, citrus propagation occurs in nurseries by grafting of budwoods. Thus, we determined the transgene expression stability and the silencing trigger in clonal replicates of the ihpCP-10 and -15 mother plants, which were 10 -years-old at the time of propagation. Ten replicates were prepared for each line by bud grafting onto nontg rough lemon rootstock. After scion development, molecular analyses of the leaf tissues were performed.

The mRNA-ihpCP accumulation was measured in the mother plants and their replicates. This involved analysis of the mature leaves of each ihpCP line mother plant $\left(\mathrm{P}^{0}\right)$, its replicates $\left(\mathrm{P}^{1}\right)$, and the non-tg control by RT-qPCR optimised for ihpCP transcript detection (De Francesco et al. 2015). Figure 1 shows that both, the mother plant and the replicates of each line, accumulated mRNA-ihpCP at a low level compared to the ubiquitin mRNA. The range and standard deviation of mRNA-ihpCP levels found among five individuals of each line were: [2.68-12.70] \pm 3.92 for ihpCP-10 $\mathrm{P}^{0},[4.64-13.73] \pm 3.63$ for ihpCP-10 $\mathrm{P}^{1}$, $[3.32-14.70] \pm 4.71$ for ihpCP-15 $\mathrm{P}^{0}$, and [3.49$15.80] \pm 4.64$ for ihpCP-15 $\mathrm{P}^{1}$. Quantitative analysis confirmed that the transgenic plants were not significantly different $(P>0.05)$. Therefore, mRNA-ihpCP had been expressed in mother plants and replicates, and both had comparable transcript accumulation. 


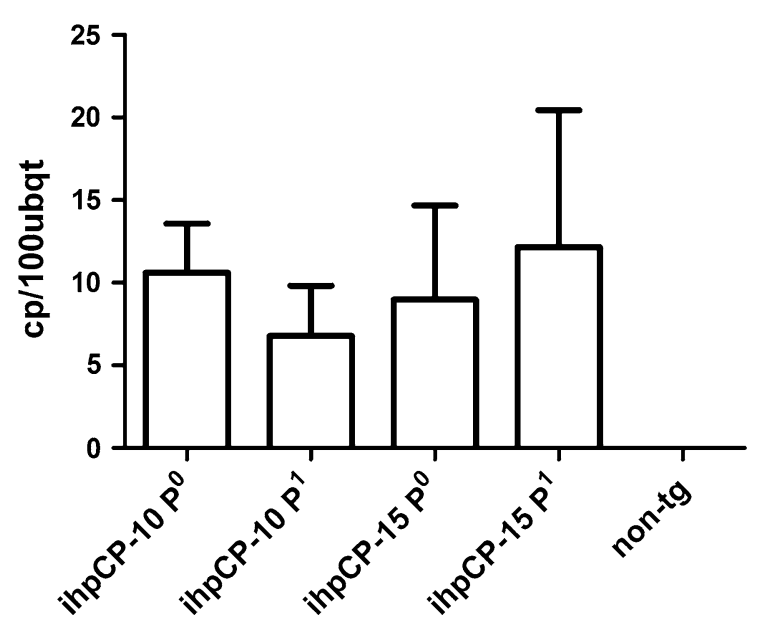

Fig. 1 mRNA-ihpCP accumulation in ihpCP-10 and -15 mother plants $\left(\mathrm{P}^{0}\right)$, their propagations $\left(\mathrm{P}^{1}\right)$, and the non-tg control, determined by RT-qPCR. The values along the y-axis show the number of copies of amplicon CP1c/CP3 (cp) per 100 copies of ubiquitin (100 ubqt). The non-tg control did not show amplification. Standard errors are indicated by the top bars with 95\% confidence

Northern blot analysis was performed to determine siRNA accumulation in the ihpCP-10 and $-15 \mathrm{P}^{1}$ plants (Fig. 2). Both lines accumulated detectable levels of siRNA derived from the transgene, as found in mother plants by Reyes et al. (2011). This indicated that no substantial changes have occurred in the ihpCPsiRNA production, after its bud-propagation. In this analysis siRNA species of approximately 21 and $24 \mathrm{nt}$ were detected in both lines.

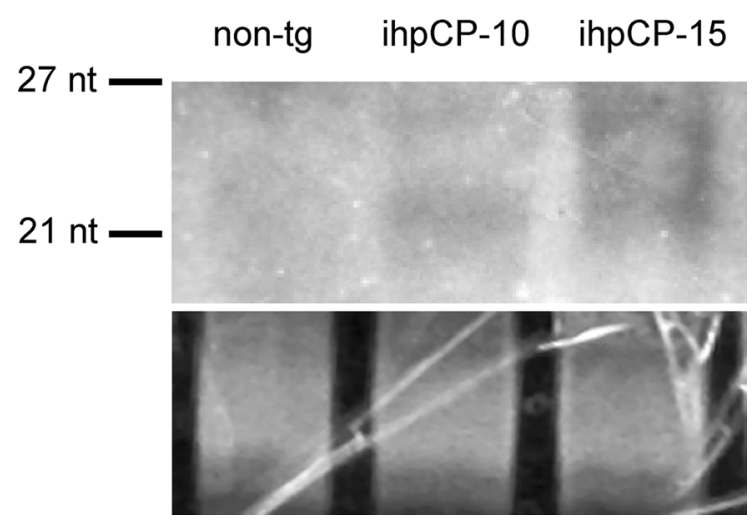

Fig. 2 siRNA-ihpCP accumulation of ihpCP-10 and -15 lines propagated onto rough lemon, and non-tg sweet orange as the negative control, determined by northern blot. The DNA oligomer size markers (21- and 27-mer) are indicated. Ethidium bromide-stained rRNA is shown as a loading control
These combined results provided evidence that the ihpCP transgene was stably expressed in plants vegetatively propagated from adult mother plants.

IhpCP-15 line shows durable resistance against the homologous PsA isolate

The ihpCP-10 and -15 lines were $\mathrm{CPsV}$ resistant through three successive flushes, for 6 months (Reyes et al. 2011). However, psorosis disease can take several years to manifest symptoms. Furthermore, the ihpCP scions were grafted onto rough lemon rootstock, which is highly CPsV-susceptible. To determine if the resistance of the ihpCP scions was stable over time, we analysed the ihpCP plants inoculated with CPsV 90-1-1 isolate 2 years after they were challenged by Reyes et al. (2011). In this work, we pruned the ihpCP plants (seven of each line and eight of the non-tg controls) and after the first flush, plants were analysed by symptom observation and CPsV detection. A sample was considered positive if it displayed a positive RT-PCR or TAS-ELISA result.

Table 1 (left panels) shows the individual fraction of each line that was positive by molecular detection and manifested psorosis symptoms 2 ypi, in parallel with the non-tg control. Seven of the eight inoculated non-tg plants were positive for $\mathrm{CPsV}$ by molecular detection, corroborating the analysis of Reyes et al. (2011). However, only two individuals manifested psorosis symptoms, probably due to the symptom recovery that sweet orange manifests under greenhouse conditions, as previously described (Reyes et al. 2016).

In the previous study (Reyes et al. 2011), the ihpCP10 line was negative for $\mathrm{CPsV}$ and none of the individuals showed symptoms. In this study, three of seven plants displayed symptoms after 2 years and two of them were positive by molecular detection. None of the ihpCP-15 replicates were infected, according to symptom observation and molecular tests, indicating that these plants remained resistant.

Although the recovery phenomenon has been observed in CPsV-infected plants, a non-tg sweet orange is not protected against re-inoculation with the same isolate. Therefore, it was important to confirm that the non-infected transgenic plants were stably CPsV-resistant and that it was not a temporal recovery. Thus, all individuals of the ihpCP-10 and -15 lines and 
Table 1 Evaluation of infection in transgenic lines ihpCP-10 and -15 and non-transgenic (non-tg) control plants

\begin{tabular}{lllll}
\hline & $\begin{array}{l}\text { CPsV detection } \\
2 \text { ypi }\end{array}$ & $\begin{array}{l}\text { Psorosis symptoms } \\
2 \text { ypi }\end{array}$ & $\begin{array}{l}\text { CPsV detection } \\
\text { re-inoculation }\end{array}$ & $\begin{array}{l}\text { Psorosis symptoms } \\
\text { re-inoculation }\end{array}$ \\
\hline ihpCP-10 & $2 / 7$ & $3 / 7$ & $4 / 7$ & $4 / 7$ \\
ihpCP-15 & $0 / 7$ & $0 / 7$ & $0 / 7$ & $0 / 7$ \\
non-tg & $7 / 8$ & $2 / 8$ & $8 / 8$ & $6 / 8$ \\
\hline
\end{tabular}

Symptom observation and CPsV detection (TAS-ELISA and RT-PCR) were performed 2 years post-inoculation (ypi, left panels), and after re-inoculation (right panels). Fractions express the number of positive individuals in a total of seven ihpCP-10 plants, seven ihpCP-15 plants, and eight non-tg plants

non-tg controls were re-inoculated in the scion by grafting with the homologous CPsV 90-1-1 isolate and evaluated after the first flush. All non-tg controls and four of seven ihpCP-10 plants were infected (Table 1, right panels). However, all ihpCP-15 plants remained healthy, confirming the complete and stable resistance of this line after 2 ypi.

IhpCP lines show resistance against the heterologous and severe PsB isolate

The first CPsV challenge of ihpCP plants (Reyes et al. 2011), and the second challenge in this work, were performed using the PsA isolate CPsV 90-1-1, which is $100 \%$ homologous to the ihpCP transgene. Thus, we also studied the behaviour of the ihpCP-10 and -15 lines when challenged with a PsB isolate, heterologous to the transgene. The Argentinian CPsV 189-34 isolate was selected, which has been used previously in the EAA INTA Concordia to test PsA samples by crossprotection assays (Anderson 2000).

To predict the efficacy of the CPsV 189-34 RNA 3 silencing, we first assessed the sequence identity between this isolate and the transgene. The sequences exhibited $97 \%$ identity based on local alignment. The probability that the ihpCP-siRNA could trigger silencing against CPsV 189-34 RNA 3 was then predicted, using two algorithms. The siRNAs potentially produced by the ihpCP transgene are summarised in Supplementary Table 1 . The two algorithms revealed twelve sequences. Ten of these sequences were located between the 209 and 343 nucleotides of the ihpCP fragment (344 nt in length), indicating that this region ( $3^{\prime}$ end of the ihpCP fragment) could be a hotspot for siRNA production. Thus, there is a high probability that the siRNA-ihpCP present in the ihpCP lines could target the $c p$ gene of the PsB isolate.

The response of lines ihpCP-10 and 15 against the PsB isolate was evaluated through a new challenge experiment with CPsV 189-34 isolate, by graftinoculation, in parallel with non-tg control. Eight replicates of each line were analysed; seven were inoculated and one remained non-inoculated, as a control. To assess the development of PsB syndrome in adult tissue, we monitored the evolution of infection by symptom observation and analysed the presence of $\mathrm{CPsV}$ in three successive flushes separated by 6 months (instead of every 2 months, as usually observed in PsA syndrome), to allow gum accumulation and PsB symptom development in the mature tissue.

Symptoms observed in the transgenic and non-tg plants are detailed in Supplementary Table 2. A wide range of behaviours, from asymptomatic to varying symptom intensities were found, such as flecking, spots, and shock reaction, which are common to the A and B syndromes, and other specific PsB symptoms, such as blotch and gum accumulation in limbs and mature leaves. Non-inoculated replicates of the ihpCP and non-tg control were asymptomatic. To compare the overall symptom behaviour of these lines, a symptom score was applied to each transgenic and non-tg replicate based on the sum of the individual symptoms reported in Table 1. Scores of 1-6 correspond to plants showing symptoms common to both the A and B syndromes (Reyes et al. 2016), and higher scores (7-15), correspond to plants showing PsB specific symptoms. The overall sums for the ihpCP-10 and -15 lines and non-tg control, at each successive flush, are shown in Fig. 3. 
Throughout the three flushes (18 months), the nontg inoculated plants showed the normal progression of the PsB syndrome. Most of the non-tg replicates manifested typical PsB symptoms in the first flush, including flecking, spots, and shock reaction; and leaf gum, limb blotch, and gum on the trunk. These symptoms became more intense in the second and third flush (see Fig. 4), with scores of 71, 104 and 118, for the first, second and third flush, respectively (Fig. 3).

In the first flush, all replicates of the ihpCP-10 line were asymptomatic, but in the second flush, four replicates $(1,2,4$ and 6$)$ showed spots or leaf gum, with a score of 25 (Table 1; Fig. 4). In the same replicates, the foliar symptoms intensified further in the third flush, yielding a score of 33 (Fig. 3), but they were asymptomatic in the limbs and trunk, in contrast to the non-tg control (Fig. 4). It indicates that this line had protection against limb and bark lesions. Thus, the ihpCP-10 line showed a symptom delay and attenuation with respect to the infected non-tg control, suggesting certain level of protection against the PsB syndrome induced by the CPsV 189-34 isolate.

All inoculated replicates of line ihpCP-15 were asymptomatic in the three flushes (Figs. 3, 4), and

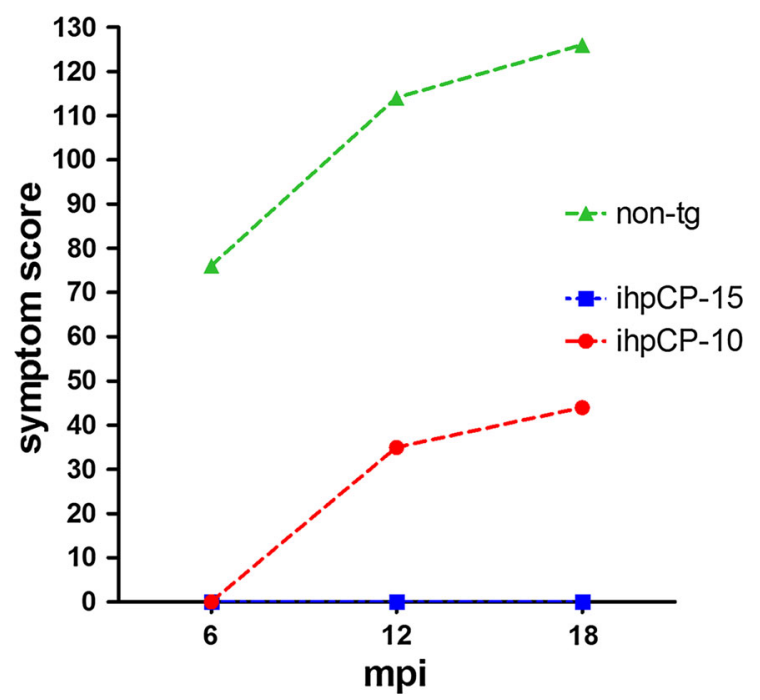

Fig. 3 PsB symptom scores of transgenic ihpCP-10 and -15 lines and non-tg control plants observed in three successive flushes, each separated by 6 months post-inoculation (mpi). Each line corresponds to the sum of the individual scores. Scores were calculated as indicated in the text indistinguishable from the non-tg non-inoculated plants.

The presence of $\mathrm{CPsV}$ was determined in each plant by RT-PCR, using primers A and B designed from the RNA 2 sequence, which is not affected by ihpCP silencing triggered on the RNA 3. Viral multiplication was quantitatively determined by measuring the coat protein levels in the three successive flushes by TAS-ELISA (Fig. 5). To assess the overall infection, TAS-ELISA values were averaged as shown in Fig. 5d. Non-tg controls yielded average values of 2.63, 3.35 and 5.25 for the first, second and third flush, respectively. They reached a highest viral titer and had a higher fraction of infected individuals in all flushes, compared to the ihpCP-10 and -15 lines (Fig. 5a-c).

The ihpCP-10 line gave variable results among the replicates. At the first flush, all ihpCP-10 replicates were negative according to TAS-ELISA and RT-PCR, although replicate 2 gave a TAS-ELISA value near the cut-off (Fig. 5a). In the second flush, three ihpCP-10 replicates (2, 4 and 6) were positive and in the third flush, replicates 1,2 and 4 were positive, by both methods. Replicate 6 became negative in the third flush, according to the molecular detection. On average, the behaviour of the ihpCP-10 line was $1.18,2.22$ and 2.57 in the first, second and third flush, respectively, according to the TAS-ELISA values. Consistent with the symptoms score, this line showed a delay in viral multiplication and protection against the CPsV 189-34 PsB isolate.

The ihpCP-15 line gave similar TAS-ELISA results among its replicates, with respective averages of 1.02, 0.89 and 1.49 for the first, second and third flushes. Thus, these replicates had a negative result for the infection and the average TAS-ELISA values were significantly lower than those of the inoculated non-tg plants. Comparable results were obtained by RT-PCR analysis, confirming that all replicates of the ihpCP-15 line were undoubtedly negative during the three analysed flushes.

To confirm the negative $\mathrm{CPsV}$ detection in plant samples of lines ihpCP-10 and -15 , we applied a specific, highly sensitive, RT-qPCR detection protocol, as previously described (De Francesco et al. 2015). Although this method also detects the ihpCP transcript present in these transgenic lines (Fig. 1), no significant differences were found in these samples with respect to the non-inoculated controls (data not 

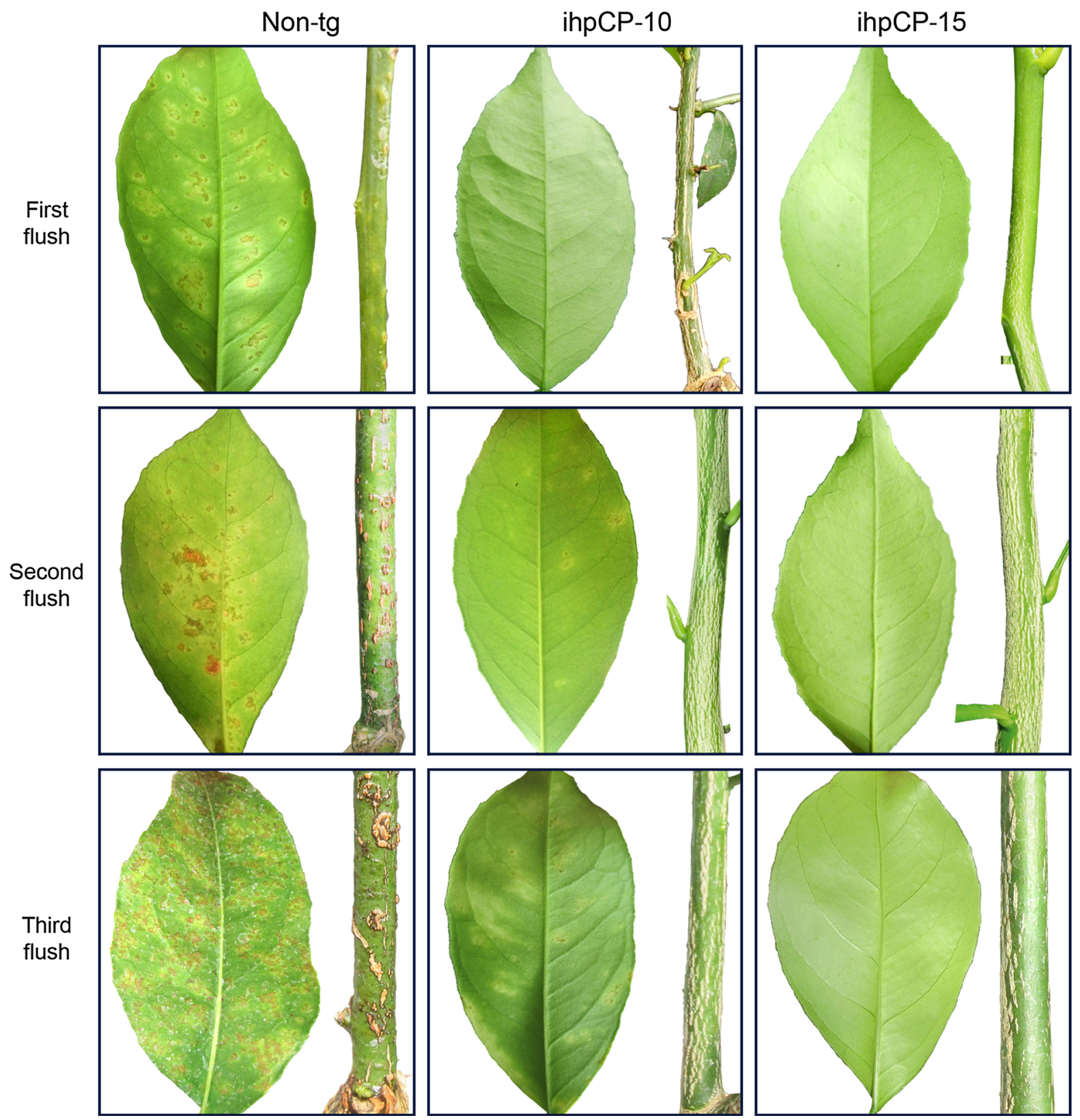

Fig. 4 Specific PsB symptoms observed in representative leaves and limbs of inoculated Citrus sinensis non-tg, ihpCP-10 and -15 plants during three successive flushes

shown), confirming the negative results obtained by TAS-ELISA and RT-PCR performed with RNA 2 primers. The results confirmed that the transgenic ihpCP-15 line was completely resistant to this PsB isolate. Moreover, infection of ihpCP-10 replicates was weaker and appeared later than the non-tg control throughout the three flushes, indicating that this line was CPsV-tolerant.

\section{Discussion}

The strong CPsV resistance shown by the ihpCP-10 and -15 lines at the time of their generation (Reyes et al. 2011), represented a promising biotechnological approach to control CPsV. Further investigations revealed that the ihpCP-15 line showed durable resistance against the homologous PsA isolate. We 


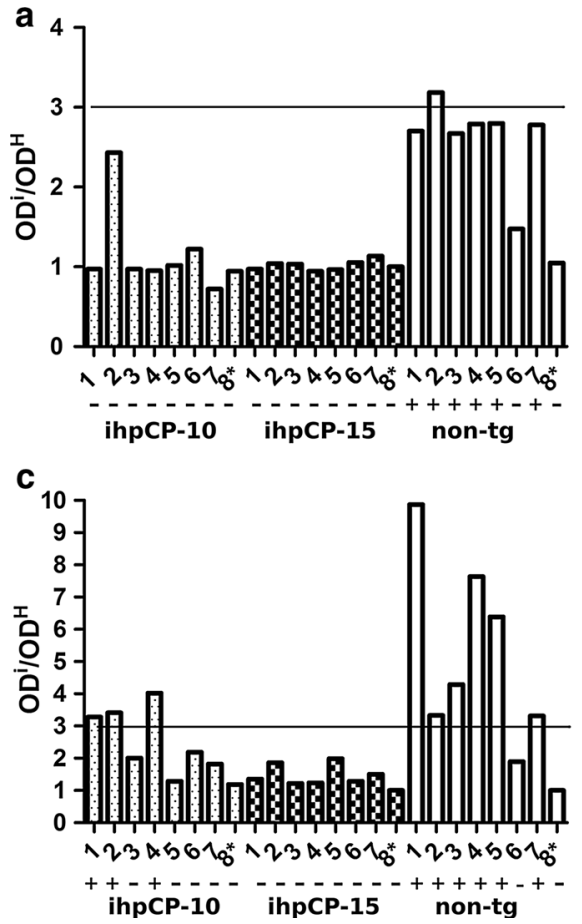

Fig. 5 Evaluation of ihpCP lines and non-tg controls challenged with PsB isolate CPsV 189-34. Virus accumulation in all replicates after successive flushes post-inoculation was determined by TAS-ELISA and RT-PCR. a first flush; $\mathbf{b}$ second flush; c third flush. $\mathrm{OD}^{\mathrm{I}} / \mathrm{OD}^{\mathrm{H}}$ indicates the average OD of infected individual triplicates divided by the average OD of the healthy control. A plant is considered infected when the OD is three

also found that graft-inoculation was highly efficient (Reyes et al. 2011), possibly more than expected by natural infection, probably due to a higher viral load. In this study, we showed that under these conditions the ihpCP-15 line still remained resistant after 2 years and after re-inoculation. Furthermore, replicates were propagated onto rough lemon rootstock, which accelerates scion growth and is highly $\mathrm{CPsV}$ susceptible. CPsV could be transported from the bud-grafted inoculum through the transgenic scion to the rootstock, where it could replicate and establish a permanent viral source, which would continuously challenge the transgenic scion. However, both ihpCP lines, in particular, the ihpCP-15, showed a high level of resistance against the homologous PsA isolate.

This work also provided additional experimental evidence of stable transgene expression in the adult mother plants and their propagations. The ihpCPderived mRNA and siRNA accumulation were
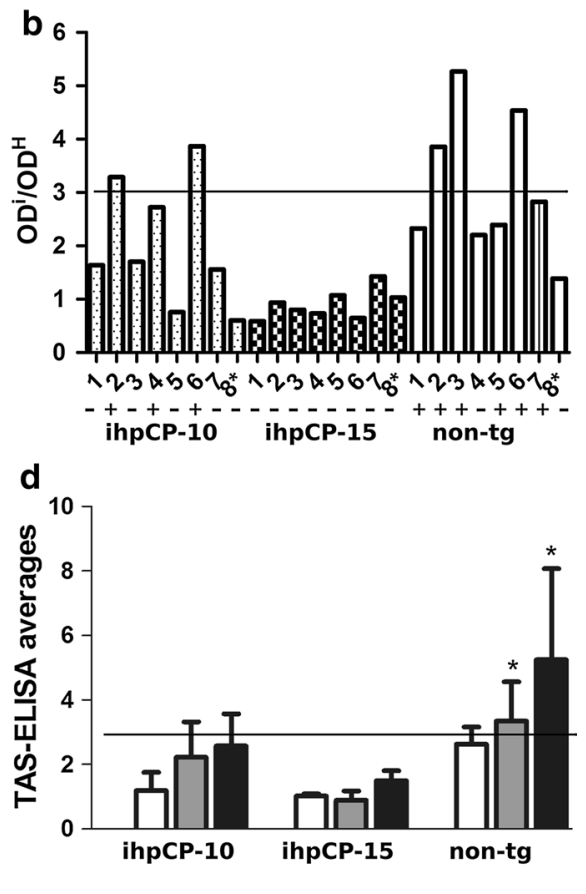

times that of the healthy control. Bottom line: RT-PCR analysis: positive (+) and negative (-) samples are indicated. d TASELISA average of all replicates of each line in the first flush (white), second flush (grey) and third flush (black). Standard error is indicated and asterisks indicate the columns with significant differences according to Tukey test with 95\% confidence

comparable among these plants, suggesting that silencing was still triggered in both transgenic lines. The fact that citrus is clonally propagated is an advantage in avoiding epigenetic changes that could affect silencing in transgenic citrus (Bond and Baulcombe 2014).

According to in silico predictions, ihpCP-siRNAs sequences could target the CPsV 189-34 RNA3 sequence, which is $97 \%$ homologous. This level of sequence identity could be sufficient to trigger the silencing of the heterologous $c p$ gene and protect the plant. siRNAs are commonly acknowledged as landmarks of RNA silencing (Brosnan and Voinnet 2011). In PTGS, dsRNA is cleaved, generating 21 and $22 \mathrm{nt}$ siRNAs, which are integrated into the RNA-induced silencing complex, and direct the target mRNA cleavage. The $24 \mathrm{nt}$ siRNA species are associated with transcriptional gene silencing (TGS) and the removal of transgene transcripts (Frizzi and Huang 2010). In the ihpCP lines, we detected both 21-22 nt 
and 24 nt siRNAs derived from the transgene, suggesting that both, TGS and PTGS, could be active. TGS has been observed after successive generations in transgenic annual crops, such as tomato (Catoni et al. 2013). Nonetheless, the risk is less probable in citrus, because they are clonally propagated by grafting of budwoods derived from adult trees. In addition, we proved that the siRNA accumulation and ihpCP transcript synthesis have not changed among the mother plants and their propagations.

In cross-protection experiments, plants infected with PsA only protect against the PsB syndrome, whereas symptoms caused by the first inoculum are still observed (Roistacher 1991). Thus, it is possible that the ihpCP lines infected with PsB isolate, would protect against PsB syndrome but allow PsA symptom expression. However, this did not occur, because the transgenic ihpCP plants were either resistant or tolerant against both syndromes.

Analysis of CPsV infection in the ihpCP-15 line after 18 months post-inoculation (mpi), revealed no symptoms and all available detection methods resulted in a negative result for each individual replicate, proving unequivocally that these plants did not contain $\mathrm{CPsV}$ and were therefore completely resistant to both PsA and PsB syndromes.

For the ihpCP-10 line, some individuals were positive for the virus, suggesting that viral replication may have been inhibited, but was not completely blocked. However, symptoms were delayed and attenuated with respect to the non-tg controls. The onset of symptoms was delayed until the second flush, although none of those individuals displayed bark lesions; instead, the infection was circumscribed to the leaf tissue. It is possible that the absence of bark symptoms at $18 \mathrm{mpi}$ is part of the delay caused by the partial inhibition of infection. Bark symptom could require a multiplication of certain virus variants with tropism to bark tissue, triggering lesions (Velázquez et al. 2012; Moreno et al. 2015). In that case, the silencing established in the ihpCP-10 plants could decrease the multiplication of the PsB variant. Finally, we conclude that the ihpCP-10 line showed tolerance to PsA and PsB syndromes 18 mpi.

The rationale for the behavioural differences evident in the ihpCP-10 and -15 lines remains unknown, but could be due to positional effects that lead to differences in siRNA expression levels, which was not strictly determined in this work. The level of resistance normally correlates with siRNA production in analogue systems (Hily et al. 2005; Gambino et al. 2010; Yadav and Chattopadhyay 2011). It is probable that the ihpCP-15 line presented a higher level of siRNA than the ihpCP-10 line, which would be consistent with the behaviour of these lines in terms of their resistance.

Our results and those reported by Reyes et al. (2011) reaffirm the hypothesis that the coat protein probably has an early and necessary role in viral replication. Therefore, it is likely that virus replication in the CPsV isolates manifesting PsA or PsB syndromes, is attenuated or prevented by a mechanism that involves the coat protein, its mRNA or the viral RNA 3 integrity. As the ihpCP-15 line is stably resistant to both PsA and PsB syndromes, this line is promising for field trials.

Acknowledgements We thank Fabián Ramos (EEAConcordia) for their observations and plant maintenance in the greenhouse. This work was supported by Agencia Nacional de Promoción Científica y Tecnológica (ANPCYT), Consejo Nacional de Investigaciones Científicas y Técnicas (CONICET), Universidad Nacional de La Plata (UNLP), and Instituto Nacional de Tecnología Agropecuaria (INTA) (PNFRU-1172; 11721; ERIOS-630081).

\section{References}

Alioto D, Gangemi M, Deaglio S, Sposato S, Noris E, Luisoni E, Milne RG (1999) Improved detection of Citrus psorosis virus using polyclonal and monoclonal antibodies. Plant Pathol 48:735-741. doi:10.1023/B:EJPP.0000041570. 28825.29

Anderson C (2000) Presentation on the Argentinean certification program. In: Proceedings of global citrus germplasm network 7-8 December 2000

Axtell MJ (2013) Classification and comparison of small RNAs from plants. Annu Rev Plant Biol 64:137-159. doi:10. 1146/annurev-arplant-050312-120043

Baulcombe D (2004) RNA silencing in plants. Nature 437:356-363. doi:10.1038/nature02874

Bond DM, Baulcombe DC (2014) Small RNAs and heritable epigenetic variation in plants. Trends Cell Biol 24:100-107. doi:10.1016/j.tcb.2013.08.001

Brosnan CA, Voinnet O (2011) Cell-to-cell and long-distance siRNA movement in plants: mechanisms and biological implications. Curr Opin Plant Biol 14:580-587. doi:10. 1016/j.pbi.2011.07.011

Catoni M, Lucioli A, Doblas-Ibáñez P, Accotto GP, Vaira AM (2013) From immunity to susceptibility: virus resistance induced in tomato by a silenced transgene is lost as TGS overcomes PTGS. Plant J 75:941-953. doi:10.1111/tpj. 12253 
Danós E (1990) La psorosis de los cítricos: la epidemia en curso en Argentina y el desafío de su control. International Foundation for Science (IFS) e Instituto Nacional de Tecnología Agropecuaria (INTA). Revista de Investigaciones Agropecuaria 22:265-277

De Francesco A, Costa N, Plata MI, García ML (2015) Improved detection of Citrus psorosis virus and coat protein-derived transgenes in citrus plants: comparison between RT-qPCR and TAS-ELISA. J Phytopathol 163:915-925. doi:10.1111/jph.12392

Di Nicola-Negri E, Tavazza M, Salandri L, Ilardi V (2010) Silencing of Plum pox virus $5^{\prime} \mathrm{UTR} / \mathrm{P} 1$ sequence confers resistance to a wide range of PPV strains. Plant Cell Rep 29:1435-1444. doi:10.1007/s00299-010-0933-6

Fawcett HS, Klotz LJ (1938) Types and symptoms of psorosis and psorosis-like diseases of citrus. Phytopathol 32:22

Fire A (1999) RNA-triggered gene silencing. Trends Genet 15:358-363. doi:10.1016/S0168-9525(99)01818-1

Folimonova SY, Harper SJ, Leonard MT, Triplett EW, Shilts T (2014) Superinfection exclusion by Citrus tristeza virus does not correlate with the production of viral small RNAs. Virol J. doi:10.1016/j.virol.2014.08.031

Frizzi A, Huang S (2010) Tapping RNA silencing pathways for plant biotechnology. Plant Biotechnol J 8:655-677. doi:10. 1111/j.1467-7652.2010.00505.x

Gambino G, Perrone I, Carra A, Chitarra W, Boccacci P, Torello Marinoni D, Barberis M, Maghuly F, Laimer M, Gribaudo I (2010) Transgene silencing in grapevines transformed with GFLV resistance genes: analysis of variable expression of transgene, siRNAs production and cytosine methylation. Transgenic Res 19:17-27. doi:10.1007/s11248-009-9289-5

García ML, Dal Bo E, Grau O, Milne RG (1994) The closely related citrus ringspot and Citrus psorosis viruses have particles of novel filamentous morphology. J Gen Virol 75:3585-3590. doi:10.1099/0022-1317-75-12-3585

Hily JM, Scorza R, Webb K, Ravelonandro M (2005) Accumulation of the long class of siRNA is associated with resistance to Plum pox virus in a transgenic woody perennial plum tree. Mol Plant Microbe Interact 18:794-799. doi:10.1094/MPMI-18-0794

Martín S, Alioto D, Milne RG, Garnsey SM, García ML, Grau O, Guerri Moreno P (2004) Detection of Citrus psorosis virus by ELISA, molecular hybridization, RT-PCR and immunosorbent electron microscopy and its association with citrus psorosis disease. Eur $\mathrm{J}$ Plant Pathol 110:747-757. doi:10.1023/B:EJPP.0000041570.28825.29

Milne RG, García ML, Grau O (2000) Genus Ophiovirus. In: van Regenmortel MVH, Fauquet CM, Bishop DHL, Carstens EB, Estes MK, Lemon SM, Maniloff J, Mayo MA, Mc Geoch DJ, Pringle CR, Wickner RB (eds) Virus taxonomy. Sevent Report of the International Committee on Taxonomy of Virus. Academic Press, New York, pp 627-631

Molnar A, Melnyk CW, Bassett A, Hardcastle TJ, Dunn R, Baulcombe DC (2010) Small silencing RNAs in plants are mobile and direct epigenetic modification in recipient cells. Science 328:872-875. doi:10.1126/science.1187959

Moreno P, Guerri J, García ML (2015) The psorosis disease of citrus: a pale light at the end of the tunnel. J Citrus Pathol

Naum-Ongania G, Gago-Zachert S, Peña E, Grau O, Garcia ML (2003) Citrus psorosis virus RNA 1 is of negative polarity and potentially encodes in its complementary strand a $24 \mathrm{~K}$ protein of unknown function and $280 \mathrm{~K}$ putative RNA dependent RNA polymerase. Virus Res 96:49-61. doi:10. 1016/S0168-1702(03)00172-2

Pall GS, Hamilton AJ (2008) Improved northern blot method for enhanced detection of small RNA. Nat Protoc 3:1077-1084. doi:10.1038/nprot.2008.67

Reyes CA, De Francesco A, Peña EJ, Costa N, Plata MI, Sendin L, Castagnaro AP, García ML (2011) Resistance to Citrus psorosis virus in transgenic sweet orange plants is triggered by coat protein-RNA silencing. J Biotechnol 151:151-158. doi:10.1016/j.jbiotec.2010.11.007

Reyes CA, Ocolotobiche EE, Marmisollé FE, Robles Luna G, Borniego MB, Bazzini AA, Asurmendi S, García ML (2015) Citrus psorosis virus $24 \mathrm{~K}$ protein interacts with citrus miRNA precursors, affects their processing and subsequent miRNA accumulation and target expression. Mol Plant Pathol. doi:10.1111/mpp.12282

Reyes CA, De Francesco A, Ocolotobiche EE, Costa N, García ML (2016) Uncontrolled Citrus psorosis virus infection in Citrus sinensis transgenic plants expressing a viral $24 \mathrm{~K}$ derived hairpin that does not trigger RNA silencing. Physiol Mol Plant Pathol. doi:10.1016/j.pmpp.2016.05.001

Robles Luna G, Peña EJ, Borniego MB, Heinlein M, García ML (2013) Ophioviruses CPsV and MiLBVV movement protein is encoded in RNA 2 and interacts with the coat protein. Virol J 441:152-161. doi:10.1016/j.virol.2013.03.019

Roistacher CN (1991) Psorosis complex: psorosis-A, psorosis-B and ringspot. In: International Organization of Citrus Virologists (ed) Graft-transmissible diseases of citrus: Handbook for detection and diagnosis. Food and Agriculture Organization of the United Nations, Rome, pp 115-126

Roistacher CN (1993) Psorosis-a review. In: Moreno P, da Graca JV, Timmer LW (eds) Proceedings of 12th conference of the international organization of citrus virologists, 23-27 November 1992, Riverside, CA, pp 139-154

Sánchez de la Torre ME, Riva O, Zandomeni R, Grau O, García ML (1998) The top component of Citrus psorosis virus contains two ssRNAs, the smaller encodes the coat protein. Mol Plant Pathol. http://www.bspp.org.uk/mppol/1998/1019sanchez

Smith NA, Singh SP, Wang MB, Stoutjesdijk PA, Green AG, Waterhouse PM (2000) Total silencing by intron-spliced hairpin RNAs. Nature 407:319-320. doi:10.1038/35030305

Velázquez K, Renovell A, Comellas M, Serra P, García ML, Pina JA, Navarro L, Moreno P, Guerri J (2010) Effect of temperature on RNA silencing of a negative-stranded RNA plant virus: Citrus psorosis virus. Plant Pathol 59:982-990. doi:10.1111/j.1365-3059.2010.02315.x

Velázquez K, Pina JA, Navarro L, Moreno P, Guerri J (2012) Association of citrus psorosis B symptoms with a sequence variant of the Citrus psorosis virus RNA 2. Plant Pathol 61:448-456. doi:10.1111/j.1365-3059.2011.02525.x

Yadav RK, Chattopadhyay D (2011) Enhanced viral intergenic region-specific short interfering RNA accumulation and DNA methylation correlates with resistance against a geminivirus. Mol Plant Microbe Interact 24(10):11891197. doi:10.1094/MPMI-03-11-0075

Zanek MC, Peña E, Reyes CA, Figueroa J, Stein B, Grau O, García ML (2006) Detection of Citrus psorosis virus in the northwestern citrus production area of Argentina by using an improved TAS-ELISA. J Virol Methods 137:245-251. doi:10.1016/j.jviromet.2006.06.021 